\title{
Opportunities for Using Smartphones in the Digital Era to Facilitate Students in Learning Sociology in High Schools
}

\author{
Taufiq Subhanul Qodr ${ }^{1 *}$, Agus Efendi², Akhmad Arif Musadad ${ }^{3}$ (D) \\ ${ }^{, 2,3}$ Department of Educational Technology, Sebelas Maret University, Surakarta, Indonesia
}

\section{A R T I C L E I N F O}

Article history:

Received March 03, 2021

Revised April 10, 2021

Accepted May 04, 2021

Available online May 25, 2021

\section{Kata Kunci:}

Peluang Penggunaan

Smartphone, Pembelajaran

Seluler, Pembelajaran

Sosiologi

Keywords:

Opportunity To Use

Smartphone, Mobile Learning,

Sociology Learning

\begin{abstract}
A B S T R A K
Perkembangan teknologi informasi mendorong penggunaan smartphone dalam berbagai bidang kehidupan sehingga membuka peluang penggunaan smartphone dalam kegiatan belajar mengajar. Tetapi guru belum bisa memaksimalkan penggunaan smartphone untuk menunjang kemampuan siswa dalam memahami materi pembelajaran. Hal ini tentunya kurang memberikan pengalaman belajar yang baik bagi siswa sehingga perlu dilakukan perbaikan sistem pembelajaran. Penelitian ini dilakukan untuk mengidentifikasi peluang penggunaan smartphone dalam memudahkan siswa belajar, khususnya dalam memahami materi pembelajaran sosiologi di SMA. Jenis penelitian ini adalah penelitian deskriptif kualitatif. Subjek penelian adalah siswa IPS kelas X SMA dengan jumlah siswa sebanyak 149 siswa. Metode pengumpulan data dalam penelitian ini adalah survey dan wawancara dengan menggunakan angket serta pedoman wawancara sebagai instrumen penelitian. Analisis data dilakukan dalam empat tahap, yaitu pengumpulan data, reduksi data, penyajian data, dan penarikan kesimpulan. Hasil penelitian ini menunjukkan bahwa terdapat peluang besar penggunaan smartphone di era digital dalam proses pembelajaran, khususnya mata pelajaran sosiologi di SMA. Peluang tersebut yaitu penyelenggaran pembelajaran seluler berbasis game atau Mobile Game-Based Learning (MGBL). Diketahui penggunaan smartphone oleh siswa paling dominan digunakan untuk bermain game dengan persentase sebesar $32.90 \%$. Dengan demikian, Mobile GameBased Learning $(M G B L)$ sebagai media pembelajaran menjadi peluang penggunaan smartphone untuk memudahkan siswa belajar sosiologi karena mendorong siswa lebih aktif, kreatif, dan inovatif dalam proses pembelajaran. Simpulan penelitian ini adalah Mobile Game-Based Learning (MGBL) menjadi peluang besar penggunaan smartphone di era digital untuk memudahkan siswa belajar sosiologi di Sekolah Menengah Atas.
\end{abstract}

\section{A B S T R A C T}

The development of information technology that encourages smartphones in various lives thus opens up opportunities for the use of smartphones in teaching and learning activities. However, teachers have not been able to maximize the use of smartphones to support students' ability to understand learning materials. This certainly does not provide a good learning experience for students, so it is necessary to improve the learning system. This study was conducted to identify opportunities for using smartphones to make it easier for students to learn, especially in understanding sociology learning materials in high school. This type of research is descriptive qualitative research. The research subjects were social studies students of class $\mathrm{X}$ SMA with a total of 149 students. Data collection methods in this study were surveys and interviews using questionnaires and interview guidelines as research instruments. Data analysis was carried out in four stages: data collection, data reduction, data presentation, and conclusion. This study indicates that there is an excellent opportunity for the use of smartphones in the digital era in the learning process, especially in sociology in high school. The opportunity is the implementation of gamebased mobile learning or Mobile Game-Based Learning (MGBL). It can be seen that the use of smartphones by students is most dominantly used to play games, with a percentage of $32.90 \%$. Thus, Mobile Game-Based Learning (MGBL) as a learning medium is an opportunity to use smartphones to make it easier for students to learn sociology because it encourages students to be more active, creative, and innovative in the learning process. This study concludes that Mobile Game-Based Learning (MGBL) is an excellent opportunity for the use of smartphones in the digital era to make it easier for students to learn sociology in high school.

This is an open access article under the CC BY-SA license.

Copyright (c) 2021 by Author. Published by Universitas Pendidikan Ganesha.

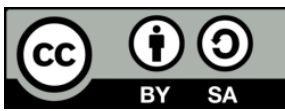

\section{INTRODUCTION}

Currently, the world is in a pandemic due to the spread of the Coronavirus. These conditions impact various fields of human life, including the field of education (Abidah et al., 2020; Ariebowo, 2021; Durnali, 2020). In education, educational institutions such as schools have transformed both in terms of implementing the 
learning process and the learning system (Baber, 2021; Jogezai et al., 2021; Yulia, 2020). In the era of the Covid-19 pandemic, face-to-face learning activities in schools have shifted to online learning activities (Garad, Al-Ansi, \& Qamari, 2021; Sari et al., 2020). Online learning activities or online learning are learning that is carried out to provide opportunities for students to interact with learning resources, both educators/environments, and their peers synchronously and asynchronously using the internet (Abidah et al., 2020; Alavudeen et al., 2021; Ariebowo, 2021). In the digital era, online learning encourages primary devices for teaching and learning activities such as smartphones (Barnes, Pressey, \& Scornavacca, 2019; Muswita et al., 2018). In this era, smartphones are a communication tool and a learning device (Lin, Hsia, \& Hwang, 2021; Troussas, Krouska, \& Sgouropoulou, 2020). This condition causes the function of technology to be more knowledge-based. The digital era can increase the speed of knowledge distribution in schools through online learning using smartphones or often called mobile learning (Bartel \& Hagel, 2014; Chang et al., 2021; Park et al., 2020). Mobile learning makes it easy for students to learn anytime and anywhere ( $\mathrm{Lu}$ et al., 2021; Sophonhiranrak, 2021). However, many things make mobile learning ineffective.

So far, teachers tend to only give assignments without providing deepening of the material to help students understand the material (Anika \& Fajar, 2020; Arianti, Wiarta, \& Darsana, 2019; Mediatati \& Suryaningsih, 2017). Teachers have not been able to maximize the use of smartphones to support students' ability to understand learning materials (Cecep, Mutaqin, \& Pamungkas, 2019; Ngabekti, Prasetyo, Hardianti, \& Teampanpong, 2019; Sunismi, 2015). This certainly does not provide a good learning experience for students so that it is necessary to improve the learning system (Agusta, 2018; Gunawan et al., 2017; Rohaeti, Suwardi, \& Ikhsan, 2013). One of the lessons that can stimulate students to develop sociological thinking skills (Pratiwi, 2017). However, the importance of critical thinking skills contained in sociology learning still cannot be optimized. This can be seen through observation activities carried out for three meetings in the learning process in the classroom through the zoom meeting \& google meet video conference platform. Through observation, information was obtained that during the learning process the teacher only focused on delivering the material orally, then continued with giving assignments according to the material presented. Furthermore, students are asked to submit assignments to teachers in the form of scientific papers without being given guidance in doing assignments, and there is no variation in assignments that make students consider the assignments from the teacher to be just a formality, without knowing that there is potential to improve critical thinking skills through assignments and sociology learning

These learning activities make students less enthusiastic and motivated in participating in learning activities, even though critical thinking skills can be embedded in students if students are enthusiastic and directly involved in various learning activities in class. During the observation activities, the teacher still did not use the latest technology to deliver the subject matter. For example, on the first day of observation, the teacher only uses the LKS owned by each student. On the second and third day, the teacher used PowerPoint as a learning medium to deliver material, but the process of delivering material was still dominated by teachers who tended to be one-way, so that students could not be maximally involved in various activities in class, both discussions and questions and answers. Therefore, the identification of a learning innovation, one of which can be circumvented through the use of technology in the learning process, such as the use of smartphones, the use of computers, and the use of the internet, is very basic and important. points to be implemented.

The current learning process must be able to see various opportunities for using digital technology, besides that students also seem to be very familiar with the use of technology, be it smartphones or computers (Kurtz, Tsimerman, \& Steiner, 2014; Velan et al., 2015; Zarzour, Bendjaballah, \& Harirche, 2020). The school learning system is expected to develop students' abilities that not only focus on academic exam preparation, but also students' critical thinking skills (Changwong, Sukkamart, \& Sisan, 2018; Saprudin et al., 2020; Yaldiz \& Bailey, 2019). Holistically, schools need to help prepare students to become critical thinkers, resilient and insightful learners, creative problem solvers, and active members of their communities. Various skills and abilities to utilize technology optimally are considered important to face the digital era that requires humans to think critically in filtering the spread of information (Chang et al., 2021; Raja \& Nagasubramani, 2018). Thinking, analyzing, and problem solving skills are useful for increasing students' potential in the future (Hussin, Harun, \& Shukor, 2018; Yamin, Saputra, \& Deswila, 2020).

Educational policymakers have developed curricula to help students develop collaboration, critical thinking, analysis, and problem solving skills (Fitri, Saparahayuningsih, \& Agustriana, 2017; Waseso, 2018). However, the development of this skill strategy depends on the teacher's teaching scenario. Some experts recommend that a curriculum that can integrate technology and authentic experiences can support student participation, motivation, and knowledge regarding the subject matter to be taught to students (Bartel \& Hagel, 2014; Dinatha \& Kua, 2019; Pradina \& Suyatna, 2018). Thus, teachers have the opportunity to develop learning media through the use of technology in the digital era such as smartphones so that the learning process provides maximum results. 
A study conducted by Marketing Emarketeer showed that the number of smartphone users in Indonesia, especially among teenagers, is multiplying. This increase in smartphone use is supported by the World Bank, which reports that more than 6 billion people have used smartphones, even a quarter of them own them personally (Susanto \& Akmal, 2018). This condition is an opportunity to use smartphones to facilitate the learning process, especially sociology subjects. Teachers can use smartphones to develop innovative and communicative learning media such as Mobile Game-Based Learning (MGBL) (Bartel \& Hagel, 2014; Troussas et al., 2020). Mobile learning using Mobile Game-Based Learning (MGBL) as a learning medium can create meaningful learning by exposing players to adaptive challenges, curiosity, self-expression, discovery, direct feedback, clear goals, player control, immersion, collaboration, competition, rewards, and low-risk failure failure (Chen \& Hsu, 2020; Kim et al., 2012; Kusuma, Suryapranata, \& Utomo, 2021). All design elements in Mobile Game-Based Learning align with established learning theories such as social constructivism and flow theory. Therefore, this type of learning media can provide learning that encourages social interaction, increases student motivation and engagement, and provides opportunities to develop valuable skills such as collaboration, creativity, communication, and critical thinking (Devraj, Colyott, \& Cain, 2021; Diacopoulos \& Crompton, 2020; Su \& Cheng, 2013).

This research is essential because, through the use of smartphones, teachers can create creative learning. Creative learning can make it easier for students to understand learning materials and encourage them to think, learn, and cooperate to improve reasoning and critical thinking so that learning objectives are achieved. MGBL in learning is an alternative solution to improve these skills (Shiow-Fern et al., 2021). Thus, cellular technology such as smartphones can be a suitable medium to facilitate learning activities. This study aims to identify opportunities for using smartphones in the digital era to facilitate students' learning process, especially sociology subjects. Sociology is a science that has an essential point in providing education about society to students when they are directly involved in society. Therefore, sociology learning must involve students' activeness by looking at various opportunities such as smartphones so that learning objectives are achieved. The purpose of this study is to analyze the opportunities for using smartphones in the digital era to make it easier for students to study sociology in high school.

\section{METHOD}

This research is a qualitative descriptive study. Through this research approach, identifying opportunities for students to use smartphones in the digital era for the learning process can be described more clearly and in-depth. The identification process begins with observation activities to analyze research data needs. After that, the researchers distributed questionnaires and then processed the research data where data processing results would be presented descriptively. The subjects of this study were social studies students of class X SMA Negeri 1 Karanganom and SMA Negeri 1 Jatianom, with 149 students. The research object is the use of smartphones by Karanganom and Jatianom high school students in the digital era. Data collection methods used in this study were surveys and interviews. Data analysis was carried out descriptively with percentages to identify opportunities for using smartphones to make it easier for students to learn sociology.

The analysis was carried out in four stages, namely, (1) data collection, (2) data reduction, (3) data presentation, and (4) concluding. Data were collected using two research instruments, namely questionnaires and interview guidelines. Data reduction in this study was carried out to filter or select data that focused on data or core findings obtained in the field. The presentation of the data is done to display descriptive data from the results of the distributed questionnaires. The conclusion stage is the final stage of research to answer how the opportunities for using smartphones in the digital era are to make it easier for students to learn sociology. The instrument used is a questionnaire consisting of 4 indicators spread over 20 questions These indicators are student responses regarding smartphone ownership, duration of smartphone use, the purpose of using smartphones, and policies implemented by schools in dealing with the massive use of smartphones during the learning process. Expert validators consulted the validity of the research instrument before the questionnaire was distributed to research subjects

\section{RESULT AND DISCUSSION}

This research was conducted by involving 149 respondents from Karanganom High School and Jatianom High School students, Klaten Regency, Central Java Province. The study results indicate that there are various opportunities for using smartphones in the digital era in the learning process, especially to make it easier for students to learn sociology in high school. The opportunities that arise cannot be separated from student ownership of smartphones. In supporting smartphone-assisted learning, one of the things that students must have is a smartphone device because schools cannot provide smartphones to support the learning process. The number 
of students who have smartphones affects the size of their opportunities in utilizing smartphones for the learning process. Data regarding smartphone ownership by Karanganom and Jatianom high school students can be presented in Figure 1. Based on Figure 1, it is known that $94.60 \%$ of Karanganom High School and Jatianom High School students have a smartphone as a technology device that helps them in completing various jobs. As a technological device that is quite flexible because it is easy to carry anywhere, students often spend quite a lot of time using smartphones. This is indicated by data regarding the duration of smartphone use by students, most of which reach more than 5 hours a day.

Data regarding the duration of students using smartphones is presented in Figure 2 below.Based on the picture, it is known that the use of smartphones by students with a duration of 1-3 hours has the least amount, which is $4.70 \%$ (7 students). Then the use of other smartphones with a duration of 3-5 hours reached $31.50 \%$ (47 students). Meanwhile, smartphones with the most extended duration or more than 5 hours have the highest number, which is $63.80 \%$ (95 students). This condition shows that the intensity of Karanganom and Jatianom high school students in using smartphones is quite long. This can be seen as the first step in creating more significant opportunities in directing students to use smartphones for positive activities such as school learning. In the next section, researchers have identified the goals or habits of students in operating smartphones. This is intended to find out how students use smartphones in daily activities. The use of smartphones by Karanganom and Jatianom high school students in more detail can be seen in Figure 3.

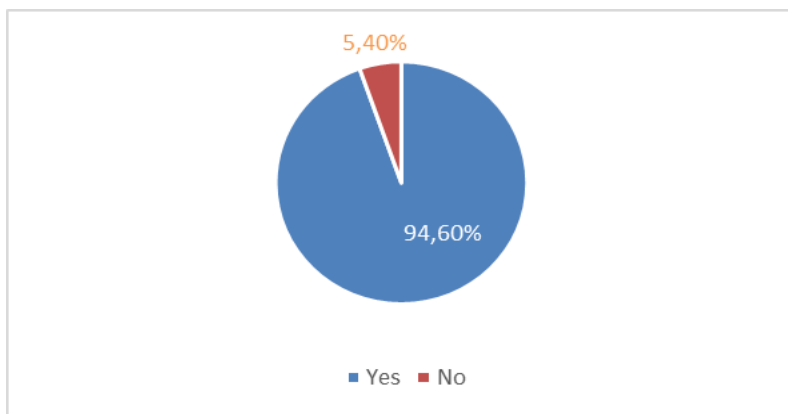

Figure 1. Student Ownership of Smartphones

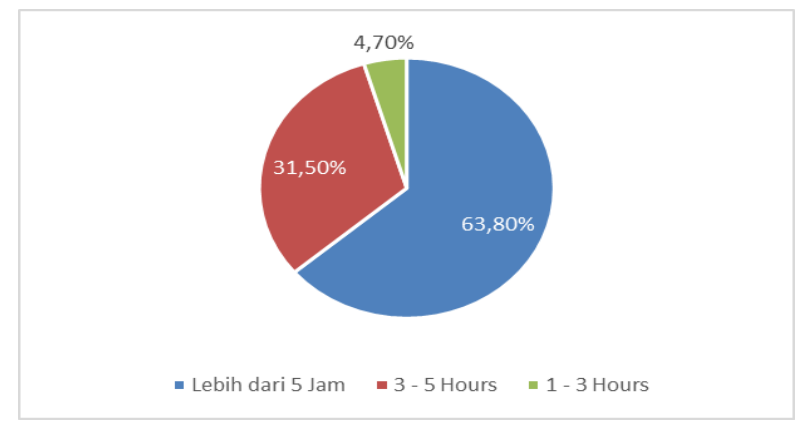

Figure 2. Duration of Students in Using Smartphones

Figure 3 shows that $32.90 \%$ of Karanganom High School and Jatianom High School students use smartphones to play games. Then $25.50 \%$ of students use smartphones to access various entertainment sites. The number of students who use smartphones to access social media reaches $22.10 \%$. At the same time, the remaining $19.50 \%$ use smartphones for the learning process. This condition shows that students have not optimized the features available on smartphones for learning activities. On the other hand, teachers are also not able to facilitate smartphone-assisted learning activities optimally, so that the use of smartphones by students still does not have clear directions and goals. Based on data on smartphone use by students who have not been maximized regarding the use of learning activities, clear regulations or policies are needed from schools to regulate smartphone use. The policies applied by schools regarding the use of smartphones in the learning process are different. Each educational institution has its policy in carrying out learning activities, including policies related to the use of smartphones to support the learning process. Karanganom and Jatianom high school students gave responses related to school policies that regulate the use of smartphones in learning activities. A more detailed picture can be seen in Figure 5.

Based on Figure 5, it can be seen that $26.20 \%$ of students stated that the use of smartphones was permitted in teaching and learning activities. However, $18.10 \%$ of students stated that it was forbidden to use smartphones in teaching and learning activities. In its implementation, this policy still depends on each subject teacher because $55.70 \%$ of students state that schools allow the use of smartphones for the learning process but are limited to certain subjects. However, overall, school policies have supported implementing a learning process that involves the use of smartphones in teaching and learning activities. 


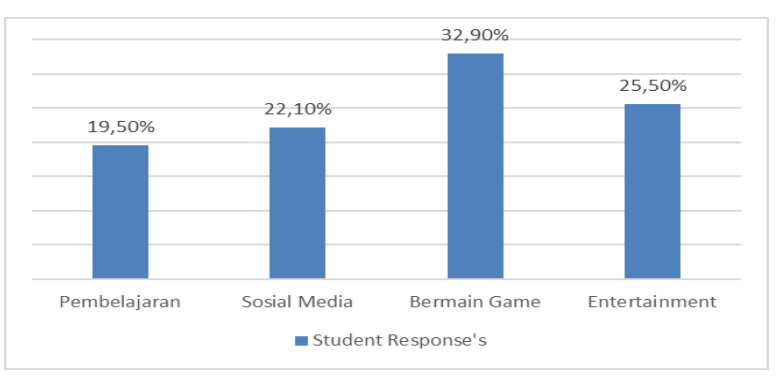

Figure 3. Student Use of Smartphones

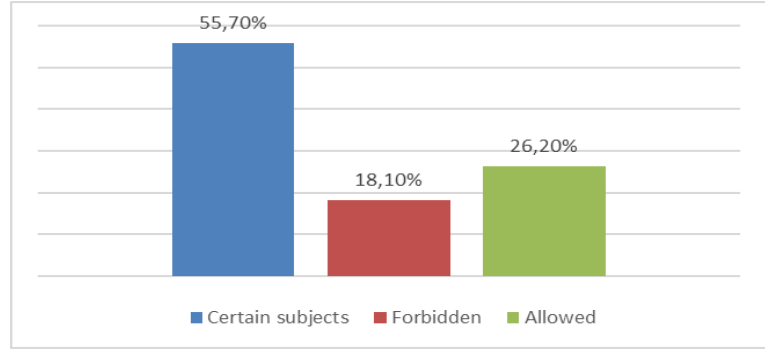

Figure 5. Policies on the Use of Smartphones in Schools

\section{Discussion}

In the digital era like today, various countries must be smart to take advantage of opportunities, considering that in that era technology played an important role in human life. Likewise with the world of education. The education sector is considered quite important considering its role in developing the capabilities and potential of human resources. Integration between technology and education will be able to provide various positive impacts and can quickly increase the capacity and quality of human resources (Budiarto, Joebagio, \& Sudiyanto, 2020; Nithyanantham, Paulmony, \& Ramadan H., 2019) One of the technologies that are currently widely used in various fields of human life, including the field of education, is a smartphone. Based on the data that has been presented in the results section, it can be seen that there are opportunities to use smartphones in the learning process, especially sociology subjects in high school. Opportunities that arise from the use of smartphones in the digital era are the function of smartphones as technological devices used in the learning process or better known as mobile learning (Alshammari, 2020; Hanif, Asrowi, \& Sunardi, 2018; Talib et al., 2019).

Mobile learning can have a positive impact on the learning process, such as making it easier for students to learn, increasing learning motivation, learning outcomes and student skills (Mahdi, 2018; Suryanda, Sartono, \& Sa'diyah, 2019). In addition, smartphone-based learning can also help students master the skills needed in today's digital era, such as critical thinking skills, innovation, communication skills, and technological literacy (Efendi, 2019; Nursyifa, 2019). The results of this study indicate that students are familiar with the use of smartphones. A total of $94.60 \%$ of students already own a smartphone, the majority of which use the Android operating system. Awareness of students in using smartphones for learning activities is quite low. This is known from the results of the questionnaire which shows that the use of smartphones for the learning process ranks the lowest, which is only $19.50 \%$. While the highest order is occupied by students who use smartphones to play games, which are $32.90 \%$.

When associated with the opportunities that arise from the use of smartphones in the learning process, these results can be utilized by educators to develop more innovative and creative learning media. This opportunity cannot be separated from the combination of smartphones as learning media that can be filled with game-based learning applications or Mobile Game-Based Learning (MGBL). The use of game-based learning media in learning has succeeded in increasing student understanding and student motivation in participating in learning activities (Kim et al., 2012; Su \& Cheng, 2013). Learning media using game-based learning applications can encourage students to be more focused and maximize the use of smartphones as a fun learning medium (Bartel \& Hagel, 2014; Troussas et al., 2020). Although packaged in the form of training, there is an interactive element in the media. Games are also used as learning media for vocabulary mastery. These various studies show that the use of smartphones in the learning process or mobile learning, especially those based on games, has a very large opportunity to be used in the learning process (Greipl, Moeller, \& Ninaus, 2020; Sari et al., 2019). If implemented in sociology subjects, Mobile Game-Based Learning (MGBL) can be used as an alternative learning media that makes it easier for students to learn and dismisses the stigma of sociology as a theoretical science that tends to be boring. Considering that so far teachers have only used printed books, powerpoint media, youtube, and student worksheets as a means of supporting the learning process in the classroom so that it has an impact on the decline in interest in learning and student achievement.

Another factor that opens up opportunities for implementing smartphone-based learning is school policy (Rorita, Ulfa, \& Wedi, 2018). The results of this study indicate that schools place their institutions as supporting the smartphone-assisted learning process. This can be seen from the students' responses which stated that $55.70 \%$ of teachers allowed using smartphones in certain subjects. In addition, overall $26.20 \%$ of students stated that while participating in learning activities students were allowed to use smartphones. Therefore, this research is very important as a basis for educators in preparing digital space-based learning facilitated by the presence of smartphones in supporting the learning process.

The results of this study indicate that there is a huge opportunity for mobile learning to be used in the learning process (Emerson et al., 2020; Greipl et al., 2020). Mobile Game-Based Learning (MGBL) can make it 
easier for students to learn sociology in high school because learning materials can be delivered more easily in a way that encourages student activity and creativity in learning. Through the use of mobile learning-based technology and support from educational institutions (schools), it is expected to create a dynamic, fun, and active learning environment (Hendi, Caswita, \& Haenilah, 2020; Partovi \& Razavi, 219AD; Sulistio \& Qohar, 2020). Overall, Mobile Game-Based Learning (MGBL) can be an innovative learning media device in the digital era. This is intended to facilitate students in the learning process as an effort to form superior and competitive human resources. The potential use of mobile learning in the learning process cannot be separated from various empirical and theoretical facts that have proven that mobile learning is one of the determining factors in optimizing the learning process. Other researchers can use this research as a basis for exploring the development and utilization of game-based smartphone learning media products for other subjects. The use of smartphones for the learning process has an important role in being able to create a conducive learning atmosphere so that students will feel helped and motivated in participating in learning activities.

\section{CONCLUSION}

The results of the research conducted indicate that there is a great opportunity for the use of smartphones in the digital era in the learning process, especially sociology subjects in high school. Most students who use smartphones to play games can be used by teachers as opportunities in developing learning media. The opportunity is game-based mobile learning or Mobile Game-Based Learning (MGBL) which can make it easier for students to learn sociology more actively, creatively, and innovatively. The opening of these opportunities cannot be separated from the development of technology and information in the digital era as well as school policies that allow students to use smartphones in the learning process according to an agreement with the teacher.

\section{REFERENCES}

Abidah, A., Hidaayatullaah, H. N., Simamora, R. M., Fehabutar, D., \& Mutakinati, L. (2020). The Impact of Covid-19 to Indonesian Education and Its Relation to the Philosophy of "Merdeka Belajar." Studies in Philosophy of Science and Education, 1(1), 38-49. https://doi.org/10.46627/sipose.v1i1.9.

Agusta, E. (2018). Feasibility Study Of The Development Of Scientific-Based Self-Regulated Learning Model Oriented Interactive Flash. Cakrawala Pendidikan, 37(1), 151-160.

Alavudeen, S. S., Easwaran, V., Mir, J. I., Shahrani, S. M., Ahmed Mohammed Almodeer Aseeri, A. A., Khan, N. A., \& Asiri, A. A. (2021). The influence of COVID-19 related psychological and demographic variables on the effectiveness of e-learning among health care students in the southern region of Saudi Arabia. Saudi Pharmaceutical Journal. https://doi.org/10.1016/j.jsps.2021.05.009.

Alshammari, M. T. (2020). Evaluation of gamification in e-learning systems for elementary school students. TEM Journal, 9(2). https://doi.org/10.18421/TEM92-51.

Anika, \& Fajar. (2020). Efektivitas Model Pembelajaran Kooperatif Tipe Make-A Match Dalam Meningkatkan Kompetensi Sikap Siswa dan Kompetensi Pengetahuan Siswa Pada Pelajaran IPS. Jurnal Ilmiah Sekolah Dasar, 4(1), 80-85. http://dx.doi.org/10.23887/jisd.v4i1.24047.

Arianti, Wiarta, \& Darsana. (2019). Pengaruh Model Pembelajaran Problem Posing Berbantuan Media Semi Konkret terhadap Kompetensi Pengetahuan Matematika. Jurnal Ilmiah Sekolah Dasar Undiksha, 3(4). http://dx.doi.org/10.23887/jisd.v3i4.21765.

Ariebowo, T. (2021). Autonomous learning during COVID-19 pandemic : Students' objectives and preferences. Journal of Foreign Language Teaching and Learning, 6(1), 56-77. https://doi.org/10.18196/ftl.v6i1.10079.

Baber, H. (2021). Modelling the acceptance of e-learning during the pandemic of COVID-19-A study of South Korea. The International Journal of Management Education, 19(2). https://doi.org/10.1016/j.ijme.2021.100503.

Barnes, S. J., Pressey, A. D., \& Scornavacca, E. (2019). Mobile ubiquity: Understanding the relationship between cognitive absorption, smartphone addiction and social network services. In Computers in Human Behavior (Vol. 90). https://doi.org/10.1016/j.chb.2018.09.013.

Bartel, A., \& Hagel, G. (2014). Engaging students with a mobile game-based learning system in university education. International Journal of Interactive Mobile Technologies, 8(4), 957- 960. https://doi.org/10.3991/ijim.v8i4.3991.

Budiarto, M. K., Joebagio, H., \& Sudiyanto, S. (2020). Student's View of Using Digital Learning Media in Classroom Activities: A Case of Public Senior High School in Cirebon, Indonesia. Jurnal Pendidikan Progresif, 10(1). https://doi.org/10.23960/jpp.v10.i1.202006.

Cecep, Mutaqin, \& Pamungkas. (2019). Pengembangan Modul Quick Math Berbasis Mobile Learning sebagai 
Penunjang Pembelajaran Matematika di SMA. Prisma Sains: Jurnal Pengkajian Ilmu Dan Pembelajaran Matematika Dan IPA IKIP Mataram, 7(2). https://doi.org/10.33394/j-ps.v0i0.1761.

Chang, H.-Y., Wu, H.-F., Chang, Y.-C., Tseng, Y.-S., \& Wang, Y.-C. (2021). The effects of a virtual simulationbased, mobile technology application on nursing students' learning achievement and cognitive load: Randomized controlled trial. International Journal of Nursing Studies, 120. https://doi.org/10.1016/j.ijnurstu.2021.103948.

Changwong, K., Sukkamart, A., \& Sisan, B. (2018). Critical thinking skill development: Analysis of a new learning management model for Thai high schools. Journal of International Studies, 11(2), 37-48. https://doi.org/10.14254/2071.

Chen, Y.-L., \& Hsu, C.-C. (2020). Self-regulated mobile game-based English learning in a virtual reality environmen. Computers \& Education, 154. https://doi.org/10.1016/j.compedu.2020.103910.

Devraj, R., Colyott, L., \& Cain, J. (2021). Design and evaluation of a mobile serious game application to supplement instruction. Currents in Pharmacy Teaching and Learning, 13(9). https://doi.org/10.1016/j.cptl.2021.06.032.

Diacopoulos, M. M., \& Crompton, H. (2020). A systematic review of mobile learning in social studies. Computers \& Education, 154. https://doi.org/10.1016/j.compedu.2020.103911.

Dinatha, N. M., \& Kua, M. Y. (2019). Pengembangan Modul Praktikum Digital Berbasis Nature of Science (Nos) Untuk Meningkatkan Higher Order Thinking Skill (Hots). Journal of Education Technology, 3(4), 293. https://doi.org/10.23887/jet.v3i4.22500.

Durnali, M. (2020). The effect of self-directed learning on the relationship between self-leadership and online learning among university students in Turkey. Tuning Journal for Higher Education, 8(1), 129-165. http://dx.doi.org/10.18543/tjhe-8(1)-2020pp129-165 Received.

Efendi, N. M. (2019). Revolusi pembelajaran berbasis digital (penggunaan animasi digital pada start up sebagai metode pembelajaran siswa belajar aktif). Jurnal Pendidikan, Sosiologi, \& Antropologi, 2(2). https://doi.org/10.20961/habitus.v2i2.28788.

Emerson, A., Cloude, E. B., Azevedo, R., \& Lester, J. (2020). Multimodal learning analytics for game-based learning. British Journal of Educational Technology, 51(5). https://doi.org/10.1111/bjet.12992.

Fitri, Saparahayuningsih, \& Agustriana. (2017). Perencanaan Pembelajaran Kurikulum 2013 Pendidikan Anak Usia Dini. Jurnal Ilmiah Potensia, 2(1). https://doi.org/10.33369/jip.2.1.1-13.

Garad, A., Al-Ansi, A. M., \& Qamari, I. N. (2021). The Role Of E-Learning Infrastructure And Cognitive Competence In Distance Learning Effectiveness During The Covid-19 Pandemic. Cakrawala Pendidikan, 40(1). https://doi.org/10.21831/cp.v40i1.33474.

Greipl, S., Moeller, K., \& Ninaus, M. (2020). Potential and limits of game-based learning. International Journal of Technology Enhanced Learning, 12(4). https://doi.org/10.1504/IJTEL.2020.110047.

Gunawan, G., Sahidu, H., Harjono, A., \& Suranti, N. M. Y. (2017). The effect of project based learning with virtual media assistance on student's creativity in physics. Jurnal Cakrawala Pendidikan, 1(2). https://doi.org/10.21831/cp.v36i2.13514.

Hanif, M., Asrowi, A., \& Sunardi, S. (2018). Students' Access to and Perception of Using Mobile Technologies in the Classroom: the Potential and Challenges of Implementing Mobile Learning. Journal of Education and Learning (EduLearn), 12(4). https://doi.org/10.11591/edulearn.v12i4.8398.

Hendi, A., Caswita, C., \& Haenilah, E. Y. (2020). Pengembangan Media Pembelajaran Interaktif Berbasis Strategi Metakognitif untuk Meningkatkan Kemampuan Berpikir Kritis siswa. Jurnal Cendekia : Jurnal Pendidikan Matematika, 4(2). https://doi.org/10.31004/cendekia.v4i2.310.

Hussin, W. N. T. W., Harun, J., \& Shukor, N. A. (2018). Problem Based Learning to Enhance Students Critical Thinking Skill via Online Tools. Asian Social Science, 15(1), 14. https://doi.org/10.5539/ass.v15n1p14.

Jogezai, N. A., Baloch, F. A., Jaffar, M., Shah, T., Khilji, G. K., \& Bashir, S. (2021). Teachers' attitudes towards social media (SM) use in online learning amid the COVID-19 pandemic: the effects of SM use by teachers and religious scholars during physical distancing. Heliyon, 7(4). https://doi.org/10.1016/j.heliyon.2021.e06781.

Kim, P., Buckner, E., Kim, H., \& Makany, T. (2012). A comparative analysis of a game-based mobile learning model in low-socioeconomic communities of India. International Journal of Educational Development, 3(2). https://doi.org/10.1016/j.ijedudev.2011.05.008.

Kurtz, G., Tsimerman, A., \& Steiner, O. (2014). The Flipped Classroom Answer to Future Learning? European Journal of Open, Distance and E-Learning, 17(2). https://doi.org/10.2478/eurodl-2014-0027.

Kusuma, G. P., Suryapranata, L. K. P., \& Utomo, Y. (2021). Enhancing Historical Learning Using Role-Playing Game on Mobile Platform. Procedia Computer Science, 179. https://doi.org/10.1016/j.procs.2021.01.078.

Lin, Y.-N., Hsia, L.-H., \& Hwang, G.-J. (2021). Promoting pre-class guidance and in-class reflection: A SQIRCbased mobile flipped learning approach to promoting students' billiards skills, strategies, motivation 
and self-efficacyNo Title. Computers \& 160. https://doi.org/10.1016/j.compedu.2020.104035.

Lu, H., Liu, J., Luo, Y., Hua, Y., Qiu, S., \& Huang, Y. (2021). An autonomous learning mobile robot using biological reward modulate STDP. https://doi.org/10.1016/j.neucom.2021.06.027.

Mahdi, H. S. (2018). Effectiveness of Mobile Devices on Vocabulary Learning: A Meta-Analysis. Journal of Educational Computing Research, 56(1). https://doi.org/10.1177/0735633117698826.

Mediatati, N., \& Suryaningsih, I. (2017). Penggunaan Model Pembelajaran Course Review Horay Dengan Media Flipchart Sebagai Upaya Meningkatkan Hasil Belajar PKn. Jurnal Ilmiah Sekolah Dasar, 1(2). http://dx.doi.org/10.23887/jisd.v1i2.10146.

Muswita, Utomo, A. B., Yelianti, U., \& Wicaksana, E. J. (2018). Pengembangan E-Book Berbasis Mobile Learning Pada Mata Kuliah Struktur Tumbuhan. Pendidikan Biologi, 11, 93-104. https://doi.org/10.20961/bioedukasi-uns.v11i2.23814.

Ngabekti, Prasetyo, Hardianti, \& Teampanpong. (2019). The Development of STEM Mobile Learning Package Ekosistem. Jurnal Pendidikan IPA Indonesia, 8(1), 81-88. https://doi.org/10.15294/jpii.v8i1.16905.

Nithyanantham, V., Paulmony, R., \& Ramadan H., S. (2019). Self-Perspective of 21st Century Educators: A Challenge in The Globalised Educational World. International Journal of Educational Research Review, 4(3). https://doi.org/10.24331/ijere.573869.

Nursyifa, A. (2019). Transformasi Pendidikan Ilmu Pengetahuan Sosial dalam Menghadapi Era Revolusi Industri 4.0. Jurnal Pendidikan Kewarganegaraan. https://doi.org/10.32493/jpkn.v6i1.y2019.p51-64.

Park, K.-B., Choi, S. H., Kim, M., \& Lee, J. Y. (2020). Deep learning-based mobile augmented reality for task assistance using 3D spatial mapping and snapshot-based RGB-D data. Computers \& Industrial Engineering, 146. https://doi.org/10.1016/j.cie.2020.106585.

Partovi, T., \& Razavi, M. R. (219AD). The effect of game-based learning on academic achievement motivation of elementary school students. Learning and Motivation, 68. https://doi.org/10.1016/j.lmot.2019.101592.

Pradina, L. P., \& Suyatna, A. (2018). Atom Core Interactive Electronic Book to Develop Self Efficacy and Critical Thinking Skills. Turkish Online Journal of Educational Technology-TOJET, 17(1), 17-23.

Pratiwi, P. H. (2017). Pengembangan Modul Mata Kuliah Penilaian Pembelajaran Sosiologi Berorientasi HOTS. Cakrawala Pendidikan, 36(2). https://doi.org/10.21831/cp.v36i2.13123.

Raja, R., \& Nagasubramani, P. C. (2018). Impact of modern technology in education. Journal of Applied and Advanced Research, 3(S1), 33. https://doi.org/10.21839/jaar.2018.v3is1.165.

Rohaeti, E., Suwardi, \& Ikhsan, J. (2013). Peningkatan Prestasi Dan Kemandirian Belajar Mahasiswa Melalui Pendekatan Reciprocal Teaching Dan Cooperative Learning. Cakrawala Pendidikan, 1(1). https://doi.org/10.21831/cp.v5i1.1265.

Rorita, M., Ulfa, S., \& Wedi, A. (2018). Pengembangan multimedia interaktif berbasis mobile learning pokok bahasan perkembangan teori atom mata pelajaran kimia kelas x sma panjura malang. JINOTEP (Jurnal Inovasi Dan Teknologi Pembelajaran) Kajian Dan Riset Dalam Teknologi Pembelajaran, 4(2). https://doi.org/10.17977/um031v4i22018p070.

Saprudin, S., Liliasari, L., Setiawan, A., \& Prihatmanto, A. (2020). Optical Gamification (OG); Serial Versus Random Model to Improve Pre-Service Physics Teachers' Concept Mastery. International Journal of Emerging Technologies in Learning (IJET), 15(9), 39-59. https://doi.org/10.3991/ijet.v15i09.11779.

Sari, A. I., Suryani, N., Rochsantiningsih, D., \& Suharno. (2019). The development of Android-based smartphone learning application on teaching reading comprehension. AIP Conference Proceedings. https://doi.org/10.1063/1.5139844.

Sari, Sinaga, Hernani, \& Solfarina. (2020). Chemistry Learning via Distance Learning during the Covid-19 Pandemic. TADRIS (Journal of Education and Teacher Training), 5(1). https://doi.org/10.24042/tadris.v5i1.6346.

Shiow-Fern, Dawie, D. D. S. A., Chong, W.-W., \& Jamal, J. A. (2021). Pharmacy student experience, preference, and perceptions of gaming and game-based learning. Currents in Pharmacy Teaching and Learning, 13(5). https://doi.org/10.1016/j.cptl.2021.01.019.

Sophonhiranrak, S. (2021). Features, barriers, and influencing factors of mobile learning in higher education: A systematic review. Heliyon, 7(4). https://doi.org/10.1016/j.heliyon.2021.e06696.

Su, C.-H., \& Cheng, C.-H. (2013). A Mobile Game-based Insect Learning System for Improving the Learning Achievements. Procedia - Social and Behavioral Sciences, 103. https://doi.org/10.1016/j.sbspro.2013.10.305.

Sulistio, W., \& Qohar, A. (2020). Development of Instructional Media "Game Math Comic Story" Based Android on Number. Journal of Education Research and Evaluation, 4(2).

Sulistio, W., \& Qohar, A. (2020). Development of Instructional Media "Game Math Comic Story" Based 
Android on Number. Journal of Education Research and Evaluation, 4(2), 109. https://doi.org/10.23887/jere.v4i2.22370.

Sunismi. (2015). Developing Guided Discovery Learning Materials Using Mathematics Mobile Learning Application As An Alternative Media For The Students Calculus II. Cakrawala Pendidikan, 34(3), 334-346. https://doi.org/10.21831/cp.v3i3.7340.

Suryanda, A., Sartono, N., \& Sa'diyah, H. (2019). Developing smartphone-based laboratory manual as a learning media. Journal of Physics: Conference Series, 402. https://doi.org/10.1088/1742-6596/1402/7/077077.

Susanto, H., \& Akmal, H. (2018). Efektivitas Penggunaan Aplikasi Pembelajaran Berbasis Mobile Smartphone Sebagai Media Pengenalan Sejarah Lokal Masa Revolusi Fisik Di Kalimantan Selatan Pada Siswa Sekolah Menengah Atas. Historia, 6(2). http://dx.doi.org/10.24127/hj.v6i2.1425.

Talib, A., Aliyu, Abdul Malik, A. M., Hooi Siang, K., Novopashenny, I., \& Ali, M. (2019). Sakai: A Mobile Learning Platform. International Journal of Interactive Mobile Technologies (IJIM), 13(11). https://doi.org/10.3991/ijim.v13i11.10800.

Troussas, C., Krouska, A., \& Sgouropoulou, C. (2020). Collaboration and fuzzy-modeled personalization for mobile game-based learning in higher education. Computers \& Education, 144. https://doi.org/10.1016/j.compedu.2019.103698.

Velan, G. M., Goergen, S. K., Grimm, J., \& Shulruf, B. (2015). Impact of Interactive e-Learning Modules on Appropriateness of Imaging Referrals: A Multicenter, Randomized, Crossover Study. Journal of the American College of Radiology, 12(11). https://doi.org/10.1016/j.jacr.2015.06.026.

Waseso, H. P. (2018). Kurikulum 2013 Dalam Prespektif Teori Pembelajaran Konstruktivisme. Ta'lim, 1(1), 5972. https://doi.org/10.29062/ta'lim.v1i1.632.

Yaldiz, N., \& Bailey, M. (2019). The Effect of Critical Thinking on Making the Right Decisions in the New Venture Process. Procedia Computer Science, 158, 281-286. https://doi.org/10.1016/j.procs.2019.09.053.

Yamin, M., Saputra, A., \& Deswila, N. (2020). Enhancing Critical Thinking in Analyzing Short Story "The Lazy Jack" Viewed from Identity Theory. Indonesian Journal on Learning and Advanced Education (IJOLAE), 3(1), 30-39. https://doi.org/10.23917/ijolae.v3i1.9948.

Yulia. (2020). Online Learning to Prevent the Spread of Pandemic Corona Virus in Indonesia. ETERNAL (English Teaching Journal), 11(1). https://doi.org/10.26877/eternal.v11i1.6068.

Zarzour, H., Bendjaballah, S., \& Harirche, H. (2020). Exploring the behavioral patterns of students learning with a Facebook-based e-book approach. Computers \& Education, 156. https://doi.org/10.1016/j.compedu.2020.103957. 